\title{
Explosion Bonding of Dissimilar Materials for Fabricating APS Front End Components-Analysis of Metallurgical and Mechanical Properties and UHV Applications
}

\section{Yuheng Li, Deming Shu, and Tuncer M. Kuzay Experimental Facilities Division}

\section{DISCLAIMER}

This report was prepared as an account of work sponsored by an agency of the United States Government. Neither the United States Government nor any agency thereof, nor any of their employees, makes any warranty, express or implied, or assumes any legal liability or responsibility for the accuracy, completeness, or usefulness of any information, apparatus, product, or process disclosed, or represents that its use would not infringe privately owned rights. Reference herein to any specific commercial product, process, or service by trade name, trademark, manufacturer, or otherwise does not necessarily constitute or imply its endorsement, recommendation, or favoring by the United States Government or any agency thereof. The views and opinions of authors expressed herein do not necessarily state or reflect those of the United States Government or any agency thereof.

June 15, 1994

\section{Advanced Photon Source Argonne National Laboratory}




\section{DISCLAIMER}

Portions of this document may be illegible in electronic image products. Images are produced from the best available original document. 
Explosion Bonding of Dissimilar Materials for Fabricating APS Front End Components-Analysis of Metallurgical and Mechanical Properties and UHV Applications

\author{
Yuheng Li, Deming Shu, and Tuncer M. Kuzay \\ Experimental Facilities Division
}

The front end beamline section contains photon shutters and fixed masks. These components are made of OFHC copper and GlidCop® AL-15 (dispersion strengthened copper). ${ }^{*}$ Stainless steels (304 or 316) are also used for connecting photon shutters and fixed masks to other components that operate in the ultrahigh vacuum system. All these dissimilar materials need to be joined together (for example: GlidCop® AL15/OFHC copper for ID beam stopping devices, GlidCop® AL-15/304 stainless steels for UHV seal connectors and OFHC copper/304 stainless steels for BM photon shutters). However, bonding these dissimilar materials is very difficult because of their different mechanical and thermal properties and incompatible metallurgical properties (shown in Table 1). For example, GlidCop® AL-15 consists of a pure fine copper matrix with a small amount of submicroscopic $\mathrm{Al}_{2} \mathrm{O}_{3}$ particles made by powder metallurgical technology, and it cannot be bonded by conventional fusion welding, including electron beam welding (EBW). Remelting of the copper matrix leads to agglomeration of $\mathrm{Al}_{2} \mathrm{O}_{3}$ dispersoids and recrystallization of the copper matrix in the weld zone [1].

Explosion bonding (EXW) is a bonding method in which the controlled energy of a detonating explosive is used to create a metallurgical bond between two or more similar or dissimilar materials. No intermediate filler metal, for example, a brazing compound or soldering alloy, is needed to promote bonding, and no external heat need be applied. Table 2 shows commercially available explosion bonding materials combinations [2].

Since 1991, a number of explosion-bonded joints has been designed for highthermal-load, ultrahigh-vacuum (UHV) compatible components ${ }^{* *}$ at the Advanced Photon Source (APS), currently under construction at Argonne National Laboratory [3-5]. Figure 1 shows some of the APS front end components joined by the explosion bonding process. A study of the metallurgical and mechanical properties and UHV applications of GlidCop® AL-15, OFHC copper, and 304 stainless steel explosionbonded joints has been done. This report contains five parts: (a) an ultrasonic examination of explosion-bonded joints and a standard setup; (b) mechanicalproperty and thermal-cycle tests of GlidCop® AL-15/304 stainless steel explosionbonded joints; (c) leak tests of a GlidCop® AL-15/304 stainless steel explosion-bonded interfaces for UHV application; (d) metallurgical examination of explosion-bonded interfaces and failure analysis, and (d) discussion and conclusion.

\footnotetext{
* Trademark by SCM Metal Products, Inc.

** All explosion-bonded parts were made by Northwest Technical Industries.
} 
Table 1 Metallurgical, Mechanical, and Physical Properties of Some APS Front End Materials

\begin{tabular}{|c|c|c|c|}
\hline & GlidCop® AL-15 & OFHC Copper & 304 Stainless Steel \\
\hline Alloy System & $\begin{array}{l}\text { Pure } \mathrm{Cu} \text { and } 0.28 \\
\text { Wt\% } \mathrm{Al}_{2} \mathrm{O}_{3}\end{array}$ & $99.99 \mathrm{Wt} \% \mathrm{Cu}$ & $\begin{array}{l}\mathrm{Fe}, \mathrm{Cr}, \mathrm{Ni}, \mathrm{C}, \mathrm{Mn} \text {, } \\
\mathrm{Si} \text {, et al. }\end{array}$ \\
\hline Atomic Structure & $\begin{array}{l}\text { fcc for } \mathrm{Cu} \text { and } \mathrm{hcp} \\
\text { for } \mathrm{Al}_{2} \mathrm{O}_{3}\end{array}$ & fcc for $\alpha-C u$ & fcc for $\gamma$-phase \\
\hline Microstructure & $\begin{array}{l}\text { Fine fiber-like } \mathrm{Cu} \\
\text { matrix and } 3-12 \\
\mathrm{~nm} \text { size } \mathrm{Al}_{2} \mathrm{O}_{3} \\
\text { dispersoids }\end{array}$ & $\begin{array}{l}\text { Granular- } \\
\text { crystalline } \\
\alpha \text {-phase }\end{array}$ & $\begin{array}{l}\text { Granular- } \\
\text { crystalline } \\
\gamma \text {-phase }\end{array}$ \\
\hline $\begin{array}{l}\text { Tensile Strength } \\
\text { (MPa) }\end{array}$ & $\begin{array}{l}413 \text { (as } \\
\text { consolidated) }\end{array}$ & $\begin{array}{l}330(\text { hard Cu) } 220 \\
\text { (soft Cu) }\end{array}$ & $\begin{array}{l}515 \text { (hot finished } \\
\text { and annealed) }\end{array}$ \\
\hline Hardness (HRB) & $\overline{73}$ & $52($ hard $\mathrm{Cu})$ & $\overline{92}$ \\
\hline $\begin{array}{l}\text { Elongation } \\
\text { Percentage (\%) }\end{array}$ & 24 & $\begin{array}{l}15(\mathrm{hard} \mathrm{Cu}) 50 \\
(\text { soft } \mathrm{Cu})\end{array}$ & 40 \\
\hline Melting Point $\left({ }^{\circ} \mathrm{C}\right)$ & $\begin{array}{l}1083 \text { for Cu matrix } \\
\text { and } 2050 \text { for } \\
\mathrm{Al}_{2} \mathrm{O}_{3}\end{array}$ & 1083 & 1450 \\
\hline $\begin{array}{l}\text { Thermal Cond. } \\
\text { (W/m-K) }\end{array}$ & 34.0 & 39.9 & 16.2 \\
\hline $\begin{array}{l}\text { Coeff. Thermal } \\
\text { Expa. }(\mu \mathrm{m} / \mathrm{m}-\mathrm{K})\end{array}$ & $\overline{16.5}$ & $\overline{17.7}$ & $\overline{17.3}$ \\
\hline
\end{tabular}

(a). Ultrasonic Examination of Explosion-Bonded Joints and a Standard Setup

There are several nondestructive methods, for example, radiography, ultrasonic, magnetic and penetrant, eddy current, and others, for inspecting flaws and other defects. Ultrasonic examination, however, is the most popular method for inspecting welding defects (such as non-bond, cracking, porosity, and slag lines) because of its ability to reveal fine cracks, non-bond, and to determine accurate depth location. All of the test parts joined by explosion bonding were inspected by the ultrasonic method. The ultrasonic equipment, transducer type and size, inspection mode and other technique data are given in Table 3. 
Table 2 Commercially Available Explosion Bonding Combinations

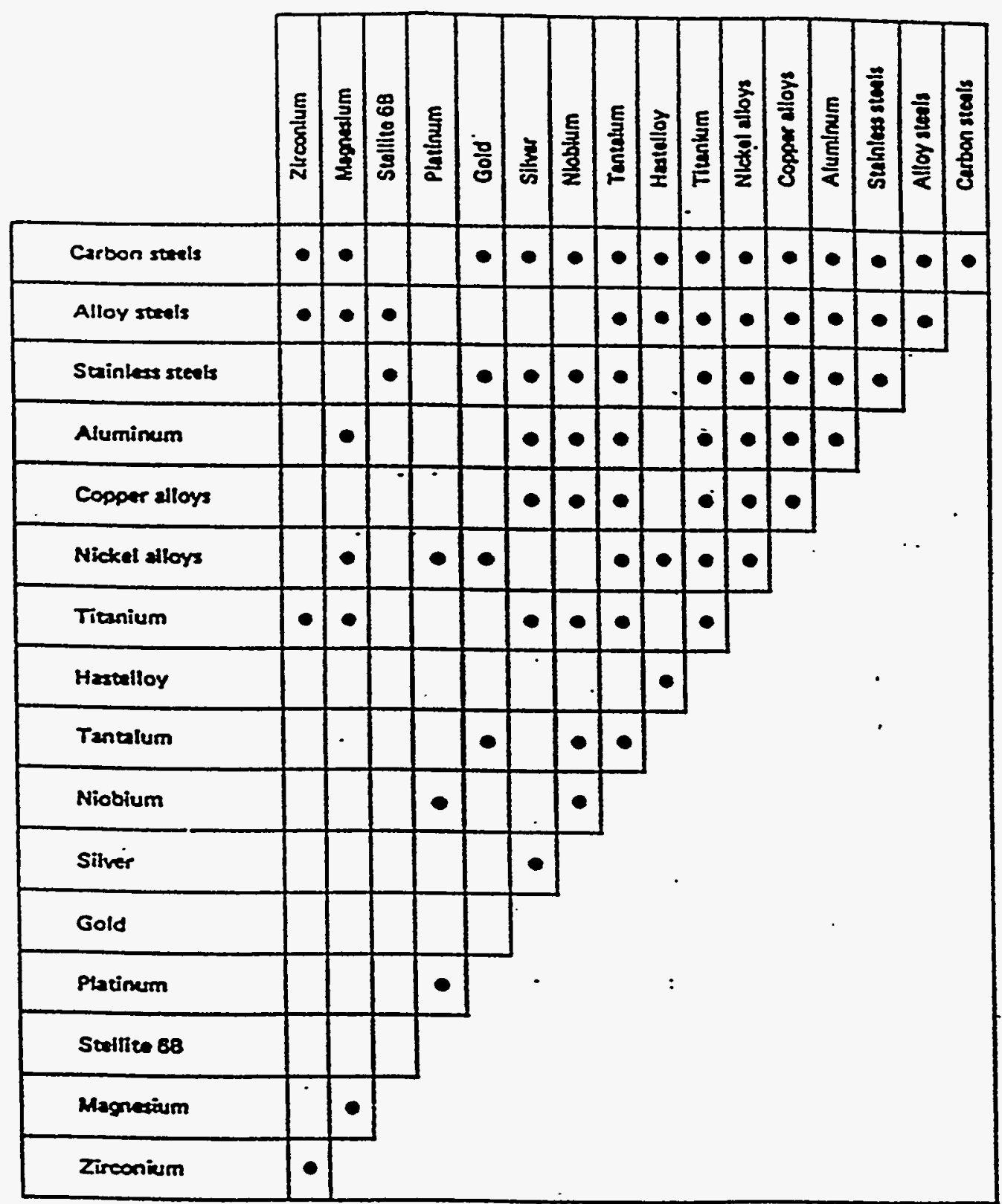

It is very important that the ultrasonic equipment is accurately calibrated so that the operator is able to assess the significance of the display with great accuracy. Improper calibration will cause false information and results. Usually, standard reference blocks are used for the calibration. A shim with the same material ad thickness as the test piece was used for calibration before the ultrasonic examination. It was recently found during the ultrasonic examination of brazing joints that more accurate results can be obtained by using a reference block with a reference hole. The reference hole can be made by drilling or electro-discharge 
machining (EDM). The tip of the hole is flat-shaped and in the bonding interface so it is easy to determine the resolution of the ultrasonic equipment and the reliability of the results. Because the ultrasonic inspection equipment and operator will vary from vendor to vendor, we must provide standard reference blocks to vendors, making them of the same materials and size. All APS front end components joined by explosion bonding and other welding processes must be ultrasonically inspected, and the equipment must be calibrated by the standard reference blocks before using.

Table 3 Technical Data for the Ultrasonic Equipment

\begin{tabular}{||l|l|}
\hline \hline Equipment Model & Sonic Mark III \\
\hline Transducer Type & Panametrics \#8900 \\
\hline Transducer Frequency & $10 \mathrm{MHz}$ \\
\hline Transducer Size and Shape & $12.7 \mathrm{~mm}$ Spherical Focus \\
\hline Inspection Method & Immersion \\
\hline Inspection Technique & Pulse Echo \\
\hline Inspection Mode & Straight Beam \\
\hline Inspection Couplant & Water \\
\hline $\begin{array}{l}\text { Estimated Resolution (Beam Focus } \\
\text { Diameter) }\end{array}$ & $0.38 \mathrm{~mm}$ to $1.50 \mathrm{~mm}$ \\
\hline Scanning Equipment Model & U.S. 640 System \\
\hline Scan Speed & $0.57 \mathrm{~m} / \mathrm{sec}$ \\
\hline Reference Standard & shims with no reference holes \\
\hline
\end{tabular}

From the ultrasonic inspection results, most of the parts joined by explosion bonding were found to be completely bonded. But small non-bond areas at the bonding edge (around $2 \mathrm{~mm}$ to $10 \mathrm{~mm}$ in length) were found in two parts, GlidCop® AL-15 round bar/304 stainless steel tubes and GlidCop® AL-15 round bar/304 stainless steel plates (shown schematically in Figure 2). This is a typical edge effect of explosion bonding. After explosion bonding, non-bond gaps usually appear at the beginning and end of explosion bonding (shown in Figure 3). The length of the non-bond gaps depends on the explosive collision velocity and the angle between the two pieces to be bonded. To overcome the edge effect of explosion bonding, extension pieces can be used in the explosive starting and ending areas. We can also bond a large piece and cut out several parts of the desired size. Otherwise, $5-10 \mathrm{~mm}$ of extra material needs to be added to the final dimensions and then machined off after explosion bonding.

\section{(b). Mechanical-Property and Thermal-Cycle Tests of GlidCop®AL-15/304 Stainless Steel Explosion-Bonded Joints}

Explosion-bonded joints of GlidCop® AL-15/stainless steel were tested. The samples size, geometry, and a special testing fixture are shown in Figure 4. A Tinius Olsen Electroautomat Testing Machine (ASD) was used for the tensile testing. The maximum load for the experiments was $2,500 \mathrm{lbs}$, and the crosshead speed was 0.05 $\mathrm{in} / \mathrm{min}$. 
In order to simulate the following fusion welding and brazing or soldering processes, the tensile samples were heated in a vacuum furnace under different heating cycles. The heat cycles, peak temperature and duration, and test results are shown in Table 4. From this table, we can see that all tensile samples were broken within the GlidCop ${ }^{\circledR}$ AL-15, even those heated up to $800^{\circ} \mathrm{C}$. Although these testing samples were not standard, we showed that these explosion-bonded joints have good mechanical and thermal properties. Standard samples will be prepared according to the AMTS for mechanical properties tests of explosion-bonded joints, and the results will be published later.

Figure 5 shows the ultimate tensile strength (UTS) of GlidCop® AL-15 as a function of temperature. It decreases from $422 \mathrm{MPa}$ at room temperature (as consolidated) to $377 \mathrm{MPa}$ after $800^{\circ} \mathrm{C}$ anda 5-minute heat cycle. However, it is still much stronger than hard OFHC copper (330 $\mathrm{MPa}$ ). After a thermal cycle, the tensile strength slightly decreases due to residual stress relief. (The residual stress is caused by hot extrusion deformation and a nonuniform cooling rate in the GlidCop® AL-15 bars.) It is expected that formability of GlidCopß AL-15 should be better after full annealing.

Figure 6 shows the tensile strength of GlidCop $®$ AL-15 as a function of heating duration at $500^{\circ} \mathrm{C}$. This change is very small (from $385.7 \mathrm{MPa}$ in $5 \mathrm{~min}$. to $383 \mathrm{MPa}$ in $30 \mathrm{~min}$.).

Figures 7 and 8 show Rockwell hardness test results (HRE) for both GlidCop® AL15 and OFHC copper after different heating cycles. It can be seen that the hardness of OFHC copper decreases from HRE 89 to 32.2 as the heating temperature increases from room temperature to $900^{\circ} \mathrm{C}$. The hardness of GlidCop@ AL-15 shows almost no change after thermal cycles (from HRE 101 to 99.5). This is because there is no microstructure change for GlidCop ${ }^{\circledR} \mathrm{AL}-15$ even after the $900^{\circ} \mathrm{C}+5 \mathrm{~min}$. thermal cycle. (The hardness depends mainly on grain size or materials microstructure.) An interesting point is that the drop in hardness for both GlidCop ${ }^{\circledR}$ AL-15 and OFHC copper is unidentifiable from 5 to 30 minutes at $500^{\circ} \mathrm{C}$. The mechanical property difference between GlidCop ${ }^{\circledR}$ AL-15 and OFHC copper after heating cycles results from their microstructure and strengthening mechanisms. GlidCop® AL-15 is composed of a fine, fiber-like copper matrix, which is strengthened by a uniform dispersion of 3-12-nm-sized $\mathrm{Al}_{2} \mathrm{O}_{3}$ dispersoids. The dispersoids are stable at elevated temperatures, up to the melting point of the copper matrix (around $1083^{\circ} \mathrm{C}$ ), and they prevent recrystallization and softening of the material when it is exposed to high temperatures [6-7]. The hard OFHC copper is strengthened by cold work (rolling or extrusion). After the cold work, a large number of subgrain boundaries, twin structures, and high density dislocations are generated, and they cause deformation hardening. At elevated temperatures, however, these strengthening structures will emigrate, emerge, and disappear as the grain size gets bigger (called recrystallization). The recrystallization temperature depends on predeformation and heating temperature. This microstructural change causes softening of the hard OFHC copper and is irreversible unless the OFHC copper is cold worked again. 
Table 4 Tensile Strength Testing of Explosion-Bonded Interfaces

\begin{tabular}{|c|c|c|c|c|c|}
\hline \multirow{2}{*}{$\begin{array}{l}\text { Sample } \\
\text { Number }\end{array}$} & \multirow{2}{*}{$\begin{array}{l}\text { Heating } \\
\text { Cycle }\end{array}$} & \multicolumn{3}{|c|}{ Tensile Rupture Position } & \multirow{2}{*}{$\begin{array}{l}\text { Rupture } \\
\text { Strength } \\
\text { (Mpa) }\end{array}$} \\
\hline & & $304 \mathrm{SS}$ & $\begin{array}{l}\text { GlidCop }{ }^{\circledR} \\
\text { AL-15 }\end{array}$ & \begin{tabular}{|c} 
Joint \\
Interface
\end{tabular} & \\
\hline 1 & \multirow{3}{*}{$\begin{array}{l}350^{\circ} \mathrm{C} \\
5 \mathrm{~min} .\end{array}$} & & $x$ & & 399.2 \\
\hline 2 & & & $x$ & & 397.8 \\
\hline 3 & & & $\mathbf{x}$ & & 397.4 \\
\hline 4 & \multirow[t]{3}{*}{$\begin{array}{l}500^{\circ} \mathrm{C} \\
5 \text { min. }\end{array}$} & & $\mathrm{x}$ & & 385.1 \\
\hline 5 & & & $x$ & & 386.4 \\
\hline 6 & & & $x$ & & 385.8 \\
\hline 7 & \multirow{3}{*}{$\begin{array}{l}800^{\circ} \mathrm{C} \\
5 \mathrm{~min} .\end{array}$} & & $x$ & & 376.1 \\
\hline 8 & & & $\underline{x}$ & & 374.4 \\
\hline 9 & & & $x$ & & 378.8 \\
\hline 10 & \multirow{3}{*}{$\begin{array}{l}500^{\circ} \mathrm{C} \\
10 \mathrm{~min} .\end{array}$} & & $\mathbf{x}$ & & 383.1 \\
\hline 11 & & & $x$ & & 382.5 \\
\hline 12 & & & $x$ & & 386.5 \\
\hline 13 & \multirow[t]{3}{*}{$\begin{array}{l}500^{\circ} \mathrm{C} \\
30 \mathrm{~min} .\end{array}$} & & $x$ & & 385.1 \\
\hline 14 & & & $x$ & & 380.7 \\
\hline 15 & & & $x$ & & 381.9 \\
\hline 16 & \multirow{3}{*}{$\begin{array}{l}\text { Room } \\
\text { Temp. }\end{array}$} & & $\mathbf{x}$ & & 430.0 \\
\hline 17 & & & $\underline{x}$ & & 427.7 \\
\hline 18 & & & $x$ & & 409.2 \\
\hline
\end{tabular}

(c). Leak Tests of GlidCop ${ }^{\circledR}$ AL-15/304 Stainless SteelExplosion-Bonded Interfaces for UHV Applications

The purpose of these experiments was to test the UHV seal ability of the explosionbonded interface and to determine what minimum bonding size is needed for a UHV 
seal. Two explosion-bonded parts were used: a 304 stainless steel tube/GlidCop ${ }^{\circledR} \mathrm{AL}$ 15 bar (Part One) and a 304 stainless steel plate/GlidCop ${ }^{\circledR}$ AL-15 plate (Part Two) (shown in Figure 9). The two parts were ultrasonically inspected, and no non-bond was found before the leak tests. After machining, the test pieces were polished by dry fine $\mathrm{SiC}$ paper in order to minimize mechanical damage and other contamination on the explosion-bonded interface.

The ASM 110 TCL leaking detector was used for these leak tests. The equipment was calibrated by Fuite Helium Calibree $( \pm 10 \% \mathrm{He})$ before examination. Table 5 shows the testing procedures and results. No leaks were found even with the bonding interface around $4.5 \mathrm{~mm}$.

Table 5 Leak Test Samples and Results

\begin{tabular}{|l||c|c|c|c||}
\hline Test Sample & $\begin{array}{l}\text { Test Length } \\
\text { of Bonding } \\
\text { Interface }\end{array}$ & $\begin{array}{l}\text { Calibration } \\
\text { (Atm.cm }\end{array}$ & $\begin{array}{l}\text { Test } \\
\text { Sensitivity } \\
\left(\text { Atm.cm }^{3} / \mathrm{s}\right)\end{array}$ & $\begin{array}{l}\text { Test } \\
\text { Result }\end{array}$ \\
\hline \hline \multirow{2}{*}{$\begin{array}{l}\text { 304 SS Tube/ } \\
\text { GlidCop }{ }^{\circledR} \text { AL-15 } \\
\text { Bar }\end{array}$} & $47 \mathrm{~mm}$ & $9 \times 10^{-8}$ & $10 \times 10^{-8}$ & No Leak \\
\cline { 2 - 5 } & $27 \mathrm{~mm}$ & $1.9 \times 10^{-8}$ & $3 \times 10^{-8}$ & No Leak \\
\hline \multirow{2}{*}{$\begin{array}{l}\text { 304 SS Plate/ } \\
\text { GlidCop } \\
\text { Plate AL-15 }\end{array}$} & $22 \mathrm{~mm}$ & $9 \times 10^{-8}$ & $10 \times 10^{-10}$ & No Leak \\
\cline { 2 - 5 } & $11 \mathrm{~mm}$ & $9 \times 10^{-8}$ & $10 \times 10^{-8}$ & No Leak \\
\cline { 2 - 5 } & $5 \mathrm{~mm}$ & $9 \times 10^{-8}$ & $10 \times 10^{-10}$ & No Leak \\
\hline
\end{tabular}

(d). Metallurgical Examination of Explosion-Bonded Interfaces and Failure Analysis

In explosion bonding, the explosive and prime metal are placed together and spaced slightly away from the backing metal. When the explosives are detonated, the prime metal collides with the backer metal. Jetting, which takes place ahead of the collision, acts to clean the joint zone, and the clean surfaces are subjected to high pressures in the collision region, causing plastic deformation at the same time. Figure 10 is a diagram of a parallel arrangement for plate explosion bonding [2].

Figures 11 and 12 show explosion-bonded interfaces of a GlidCop ${ }^{\circledR}$ AL-15 bar/304 stainless steel plate and a GlidCop ${ }^{\circledR}$ AL-15 plate/OFHC copper plate. It can be seen that explosively bonded materials preferably exhibit a wavy bond zone interface. The wavy interface is remarkable for explosion bonding because of its very regular pattern. The ability to obtain good explosion bonds is directly related to the wavy pattern. Formation of the wavy pattern can be analogous to fluid flowing around an obstacle (the point of highest pressure in the collision region for explosion bonding). When the fluid velocity (jet speed or collision velocity for explosion bonding) is low, the fluid flows smoothly around the obstacle (shown in Figure 13 (a)). As the velocity 
increases, the flow shows a wavy pattern (shown in Figure $13(\mathrm{~b})$ and (c)). When the velocity reaches a certain value, the flow pattern becomes turbulent (shown in Figure 13 (d) and (e)). The turbulent wavy interface of explosion bonding is not desirable because it develops large thermal adiabatic shear forces along the bond interface and causes shear cracks (either in the interface or the base material). Figure 14 shows a turbulent wave of GlidCop ${ }^{\circledR}$ AL-15/304 stainless steel that traps metal oxides and other contaminants ejected by jetting. Microcracks are also found in the GlidCop ${ }^{\circledR}$ AL-15 side. We may need to work with vendors to optimize bonding conditions and variables in order to minimize or eliminate the shear microcracks and other defects. (These defects may not be ultrasonically detected and thus may cause leaking problems for UHV sealing after thermal and stress cycles).

UHV sealing connectors of GlidCop ${ }^{\circledR}$ AL-15/304 stainless steel and OFHC copper/304 stainless steel need to be welded to other front end components after explosion bonding. The welding thermal cycles that follow will affect the interface properties of explosion bonding. Figure 15 shows an OFHC copper tube/304 stainless steel tube bond interface following the arc welding thermal cycle. (This part failed the ultrasonic and UHV leak tests.) It can be seen that a large amount of the brittle intermetallic compounds was formed along the interface. Over-heating during conventional arc welding will result in the remelting of explosion-bonded joints, producing brittle intermetallic compounds and decreasing the components' lifetime and UHV sealing ability.

\section{(e). Discussion and Conclusion}

1. Dissimilar materials used in APS front end components, such as 304 stainless steel, GlidCop ${ }^{\circledR} \mathrm{AL}-15$, and OFHC copper, can be joined by explosion bonding. This is especially significant for GlidCop ${ }^{\circledR} \mathrm{AL}-15$ because it cannot be joined by conventional fusion welding.

2. Preliminary test results show that GlidCop ${ }^{\circledR}$ AL-15/304 stainless steel explosionbonded joints have good mechanical and thermal properties. The property testing and manufacture processing of explosion-bonded joints need further study.

3. Explosion-bonded joints of dissimilar materials are suitable for UHV applications. A five (5) mm length of GlidCop ${ }^{\circledR} \mathrm{AL}-15 / 304$ stainless steel joints is recommended for UHV sealing.

4. All APS front end components joined by explosion bonding must be $100 \%$ ultrasonically inspected. Standard reference blocks with a reference hole should be provided to vendors. All ultrasonic equipment should be calibrated by the standard reference blocks before ultrasonic examination.

5. High energy-density welding techniques, such as electron beam welding (EBW), ion beam welding (IBW) and laser beam welding (LBW), are strongly recommended as the only welding processes to follow explosion bonding. Over-heating and remelting explosion-bonded interfaces of dissimilar materials by manual metal-arc welding 
(MAW) and metal-inert-gas welding (MIG) could result in formation of a large amount of brittle intermetallic compounds and microcracks, decreasing the bonding strength and UHV sealing ability. Tungsten-inert-gas (TIG) may be suitable as the welding process following explosion bonding with careful joint design and controlled heat input.

6. The design of extension pieces for explosion bonding is needed to eliminate the edge effect caused by the explosive jetting phenomena. Bonding a large piece and cutting it into smaller pieces of the desired size is recommended.

7. The interface formation mechanism of explosion bonding is still unclear, and controversy surrounds most of the conclusions [2 and 8-12]. A typical interface of explosion bonding is around a few angstroms to hundreds of angstroms. These scales are not analyzed by optical microscopy (OM) or even by scanning electron microscopy (SEM). A study of thermal and synchrotron x-ray radiation effects on explosion-bonded interfaces by high resolution electron microscopy (HREM) with $\mathrm{x}$ ray microanalysis (EDS) is proposed. This study will help us understand the mechanical and metallurgical properties of explosion-bonded interfaces and reliably predict the service life of APS components joined by explosion bonding.

\section{Acknowledgment}

Thanks to Dave Ryding for his contribution and support. Special thanks to Roger Massow, Charles Vulyak (non-destructive testing lab), Charles Krieger (ASD), Dave Travis, and Try Leng Kruy for their technical support.

\section{References}

1. P. Samal, The Metal Science of Joining, TMS Proceedings of International Symposium, 296, 1991

2. J. Davies et al., ASM Metals Handbook, Vol.7, 705, 1993

3. D. Shu, H. Nian, Z. Wang, J. Collins, D. Ryding and T. Kuzay, High Heat Flux Engineering, Vol.1739, 218, 1992

4. D. Shu, Y. Li, D. Ryding, and T. Kuzay, "Explosion Bonding and Its Applications in the Advanced Photon Source Front End and Beamline Components Design," to be published

5. Y. Li, D. Shu, D. Ryding, and T. Kuzay, "Explosion Bonding of GlidCop ${ }^{\circledR}$ Dispersion Strengthened Copper and Interface Analysis," to be published

6. P. Samal and A. Nadkarni, Modern Developments in Powder Metallurgy, 16,1984

7. SCM Metal Products, Inc., Technical Data, Bulletin No.1428, 1988 8. H. Mansell: Hybrid Circuit Technology, Vol.7, 67, 1990

9. B. Zhou et al., Acta Mtallurgica Sinica, Vol.25, A7, China, 1989

10. Y. Morimoto et al., Kobe Research and Development, Vol.42, 4, Japan, 1992

11. D. Anderson et al., Explosive Welding, The Welding Institute of Cambridge, England, 1976

12. L. Lazri, Welding Review, Vol.5, 74, 1988 



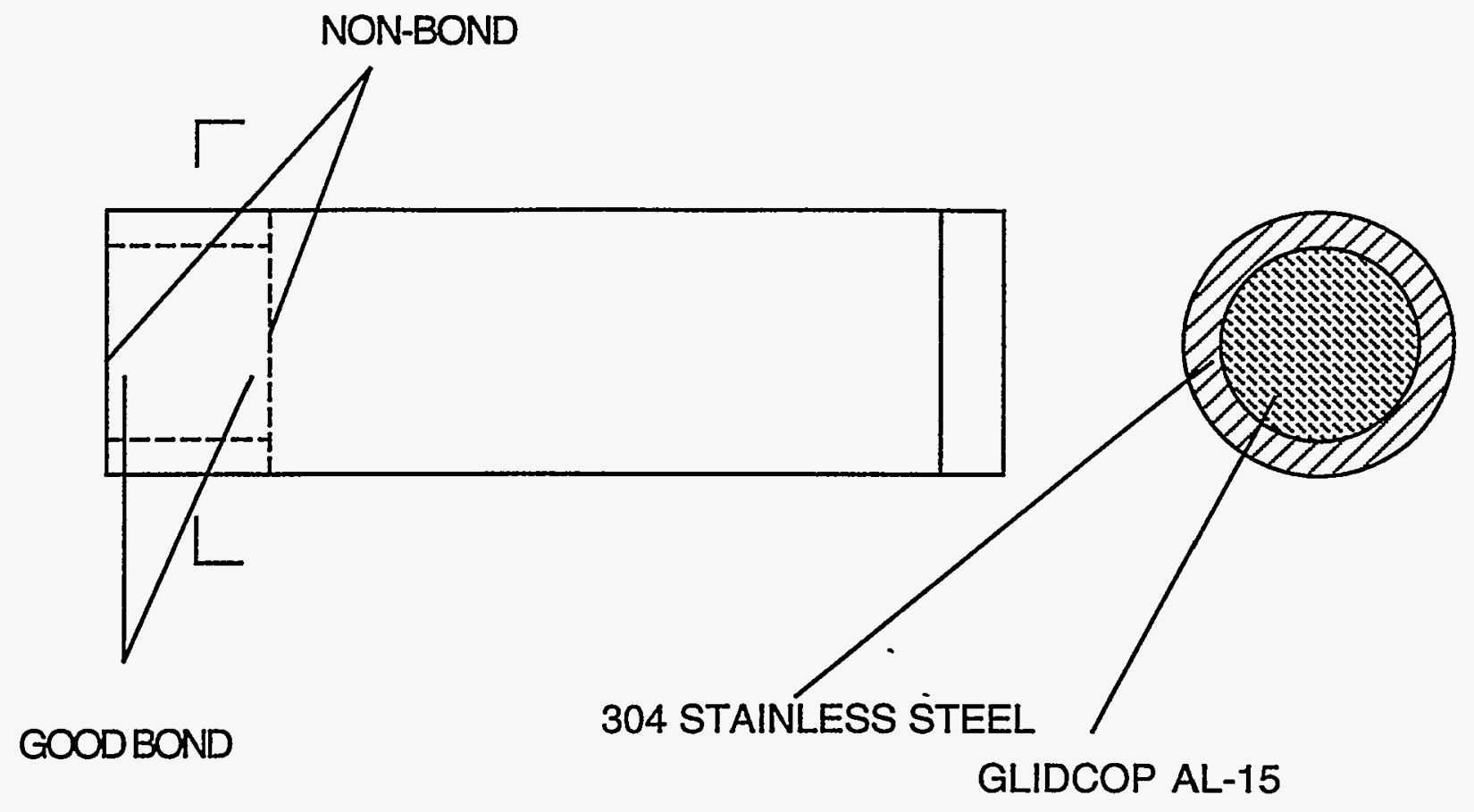

(a) GlidCop AL-15 bar/304 stainless steel tube and plate

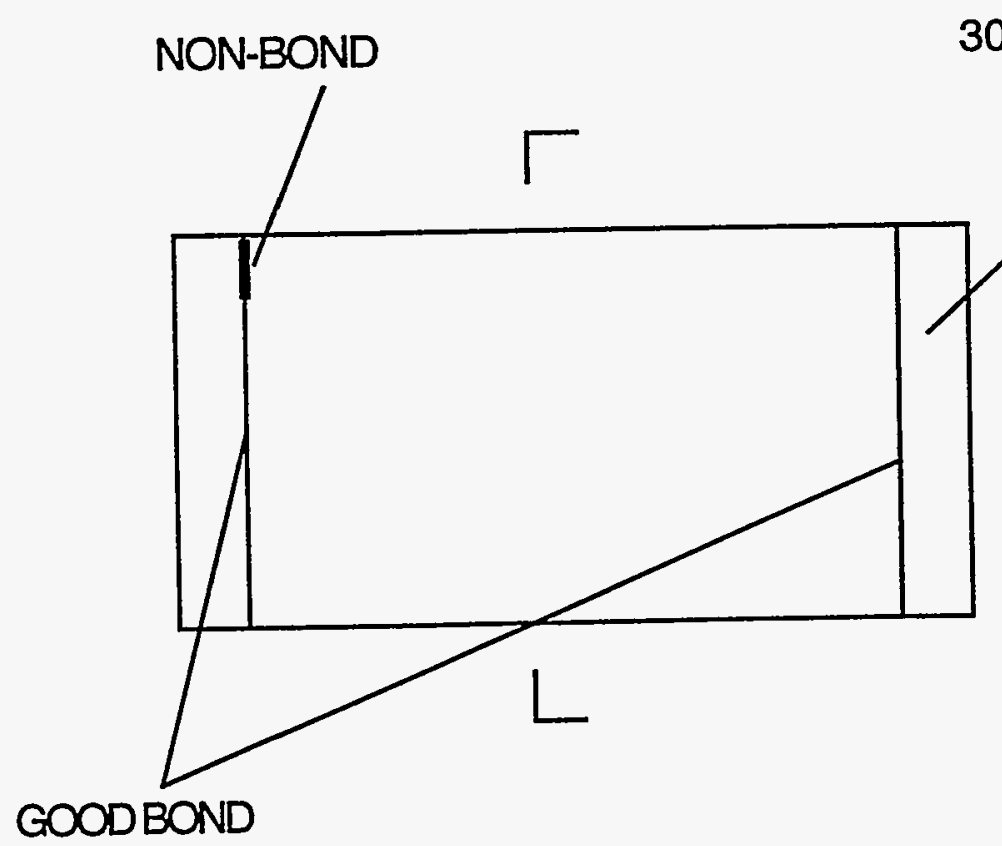

304 STAINLESS STEEL

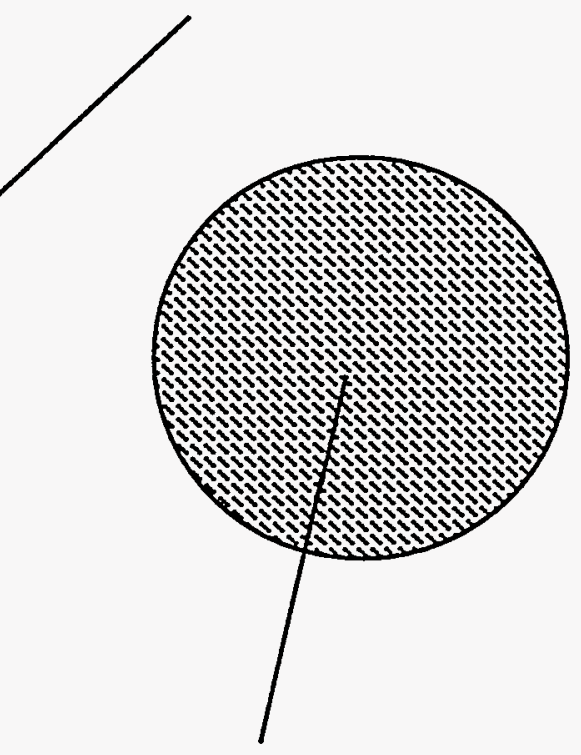

GLIDCOP AL-15

(b) GlidCop AL-15 bar/304 stainless steel plate

Figure 2. Schematic diagram of non-bond area caused by edge effect of explosion bonding 


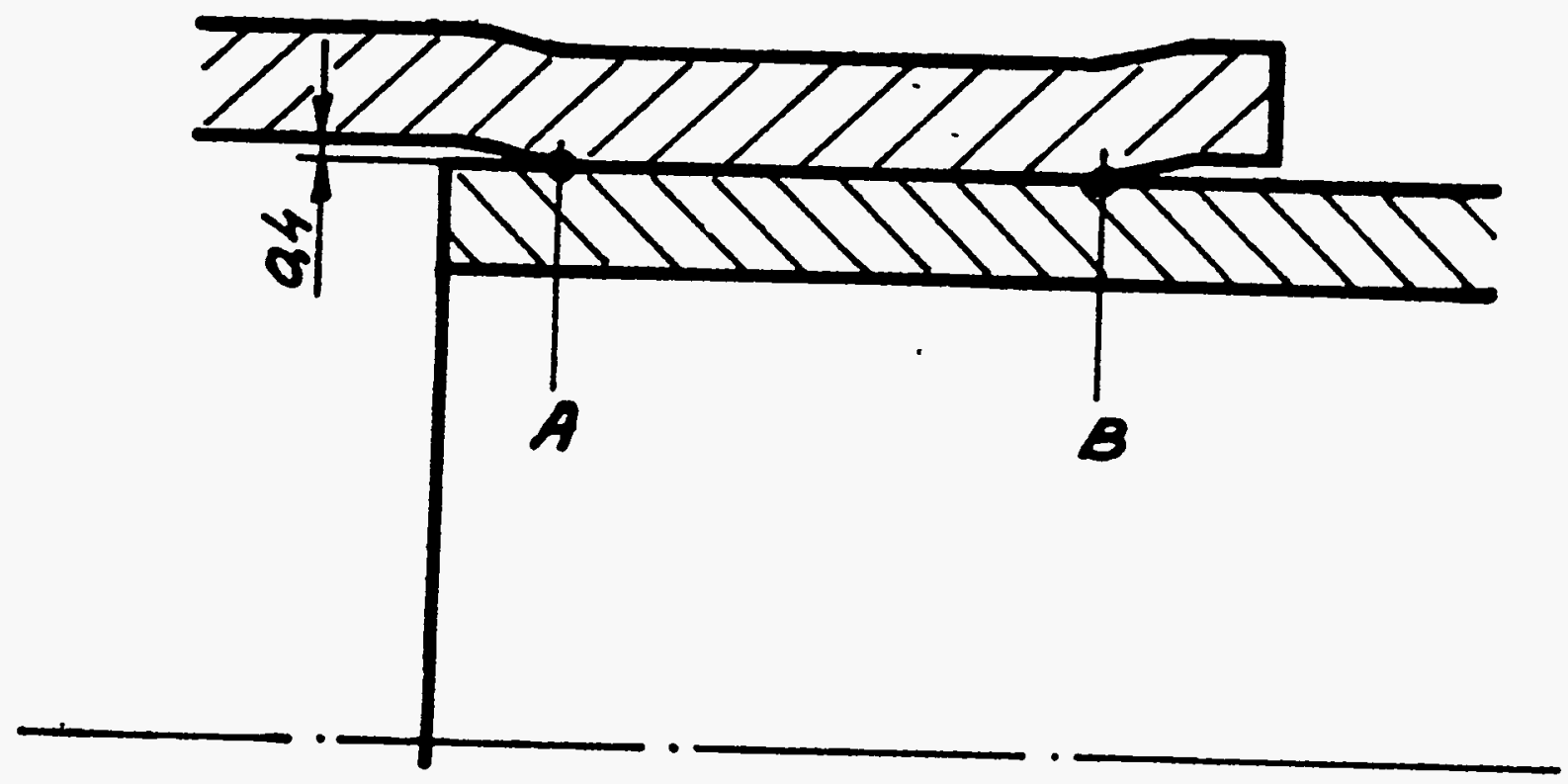

Figure 3. Schematic diagram of edge non-bond areas of explosion bonding for parallel arrangement (7) 

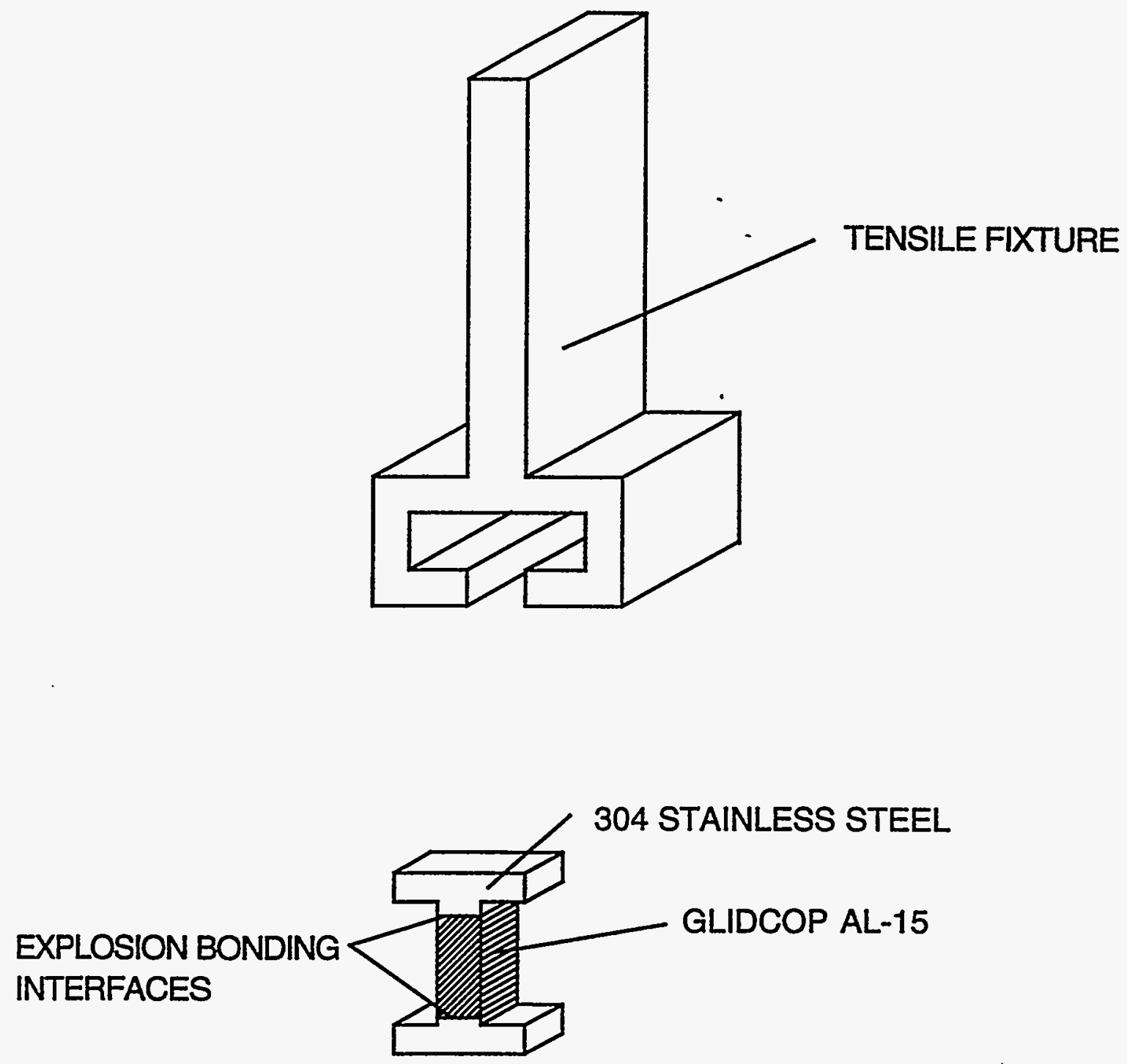

Figure 4. Schematic diagram of explosion-bonded sample for tensile testing and testing fixtures 


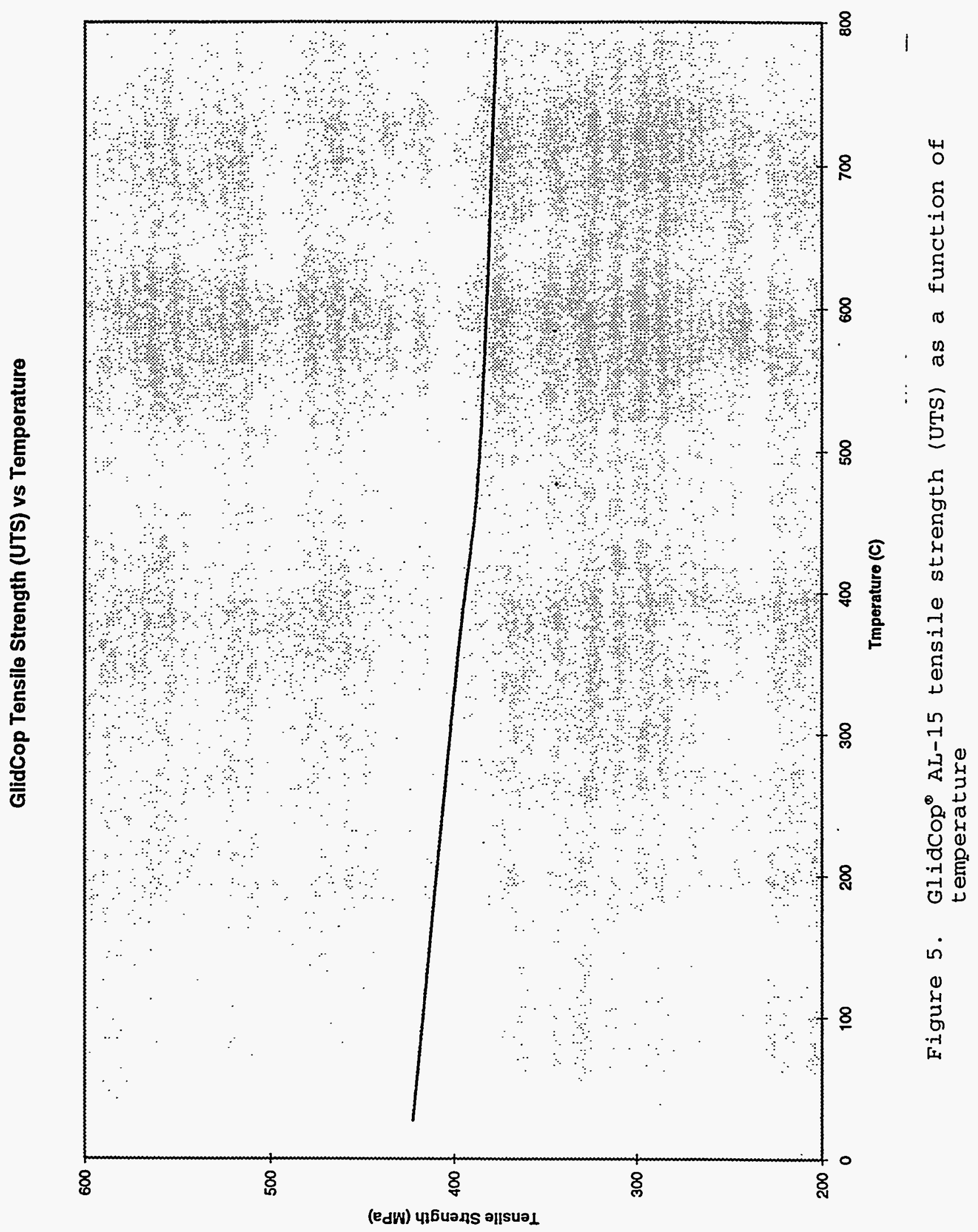




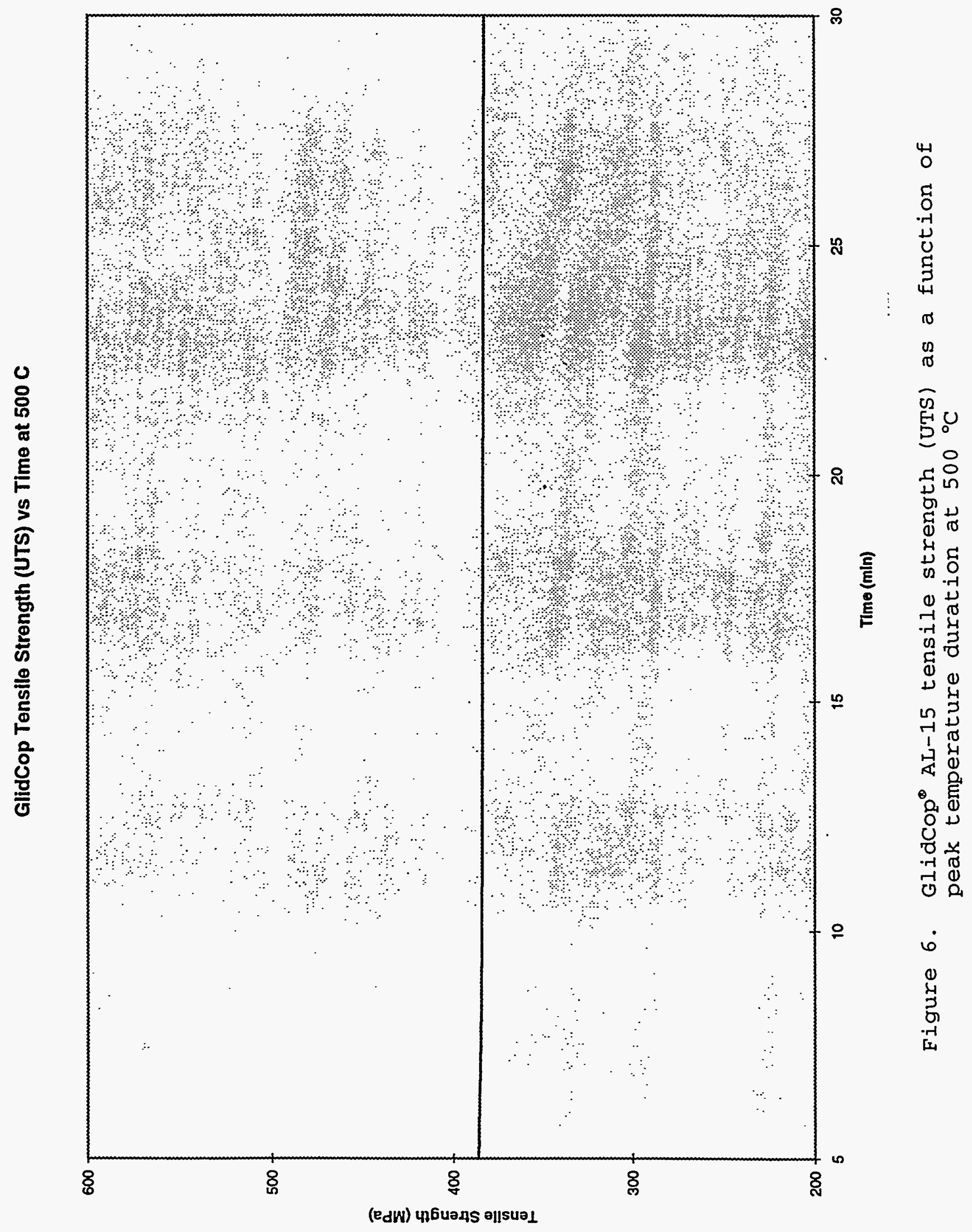


GlidCop AL-15 and OFHC Copper Hardness (HRE) vs Temperature

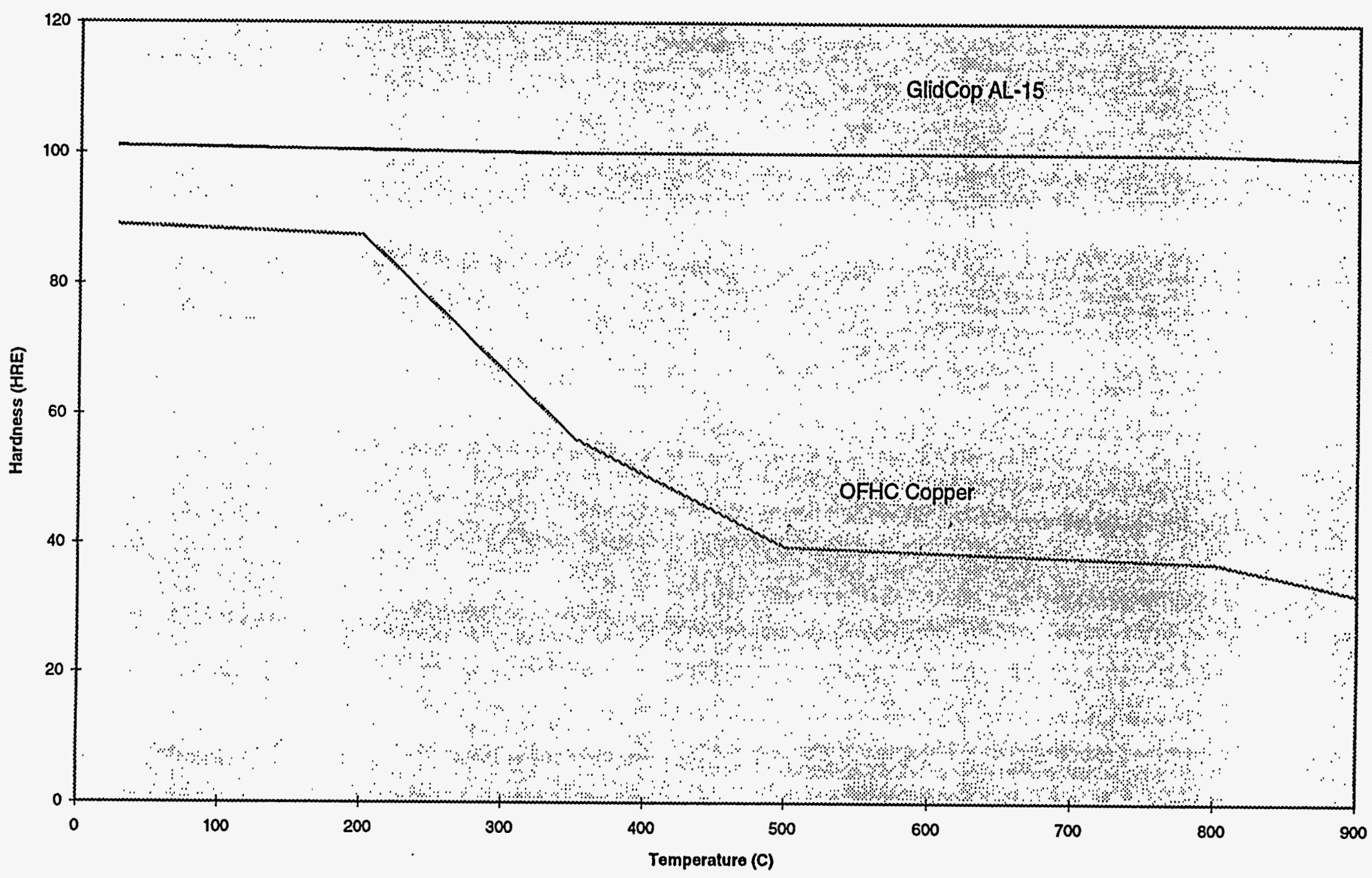

Figure 7. Rockwell hardness (HRE) of GlidCop AL-15 and OFHC copper as a function of temperature 
GlidCop AL-15 and OFHC Copper Hardness (HRE) vs Time at $500 \mathrm{C}$

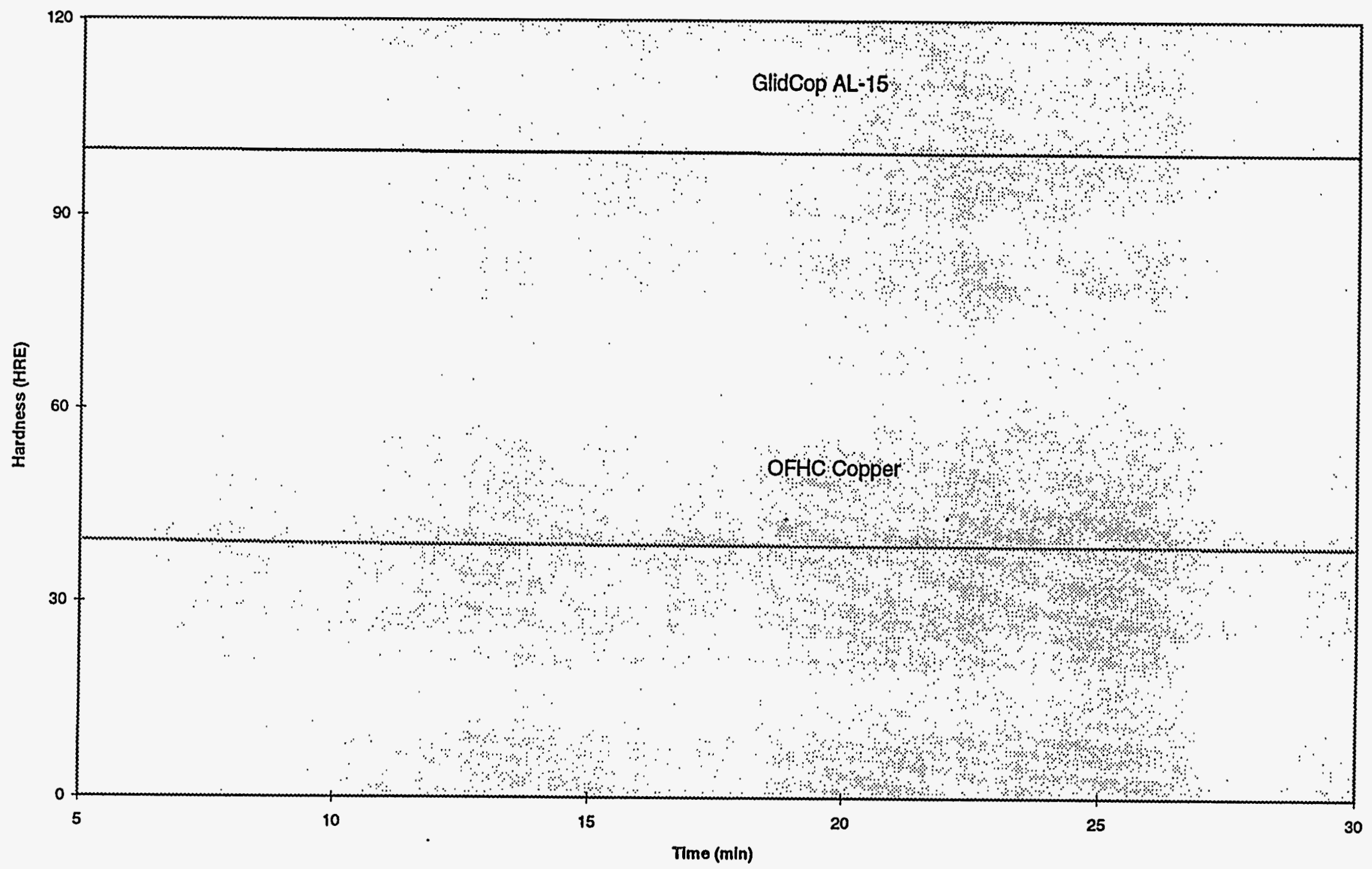

Figure 8. Rockwell hardness (HRE) of GlidCOD AL-15 and OFHC copper as a function of peak temperature duration at $500{ }^{\circ} \mathrm{C}$ 


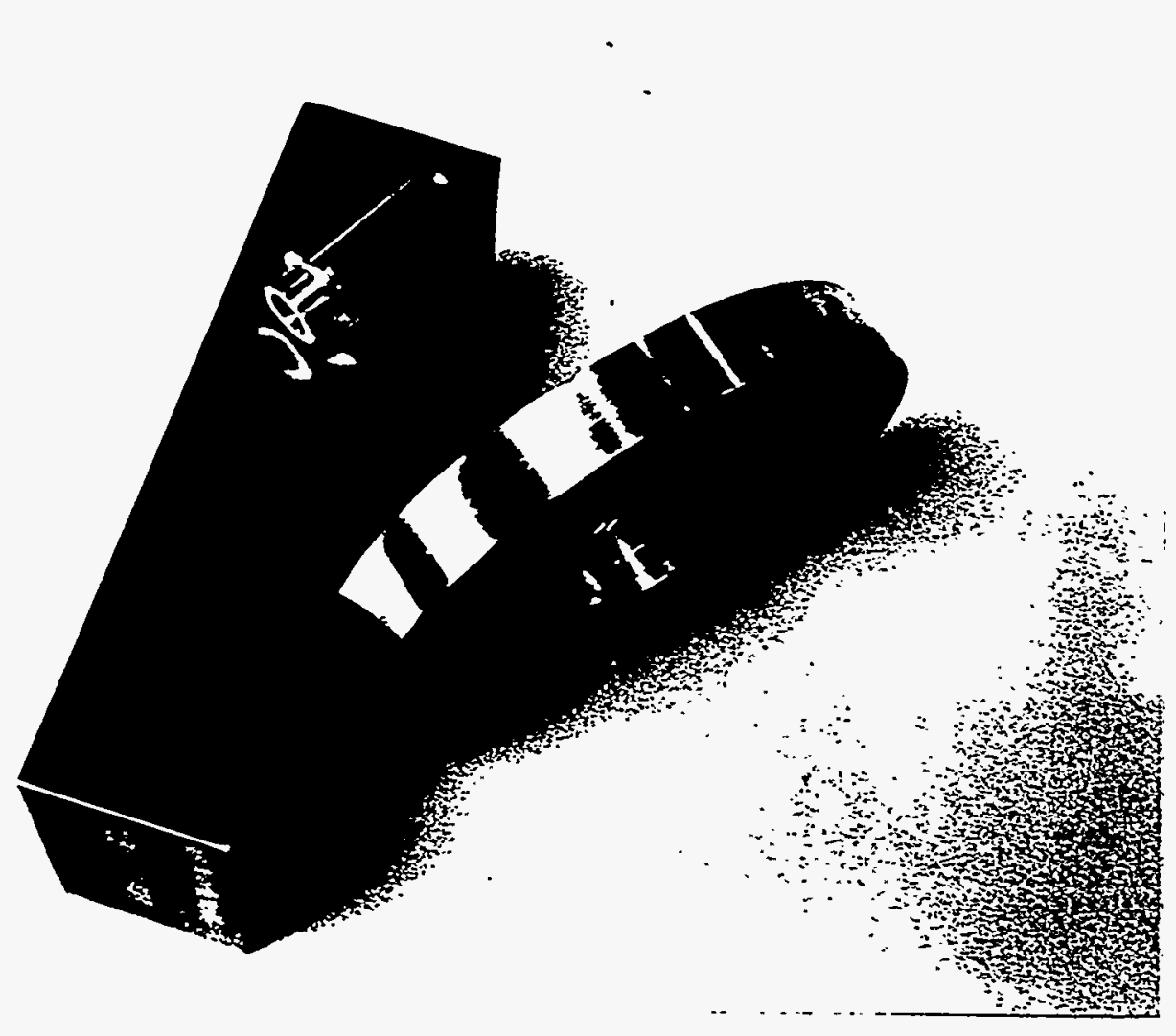

Figure 9. Photograpir of E: iozion-bonded parts for leak tests 


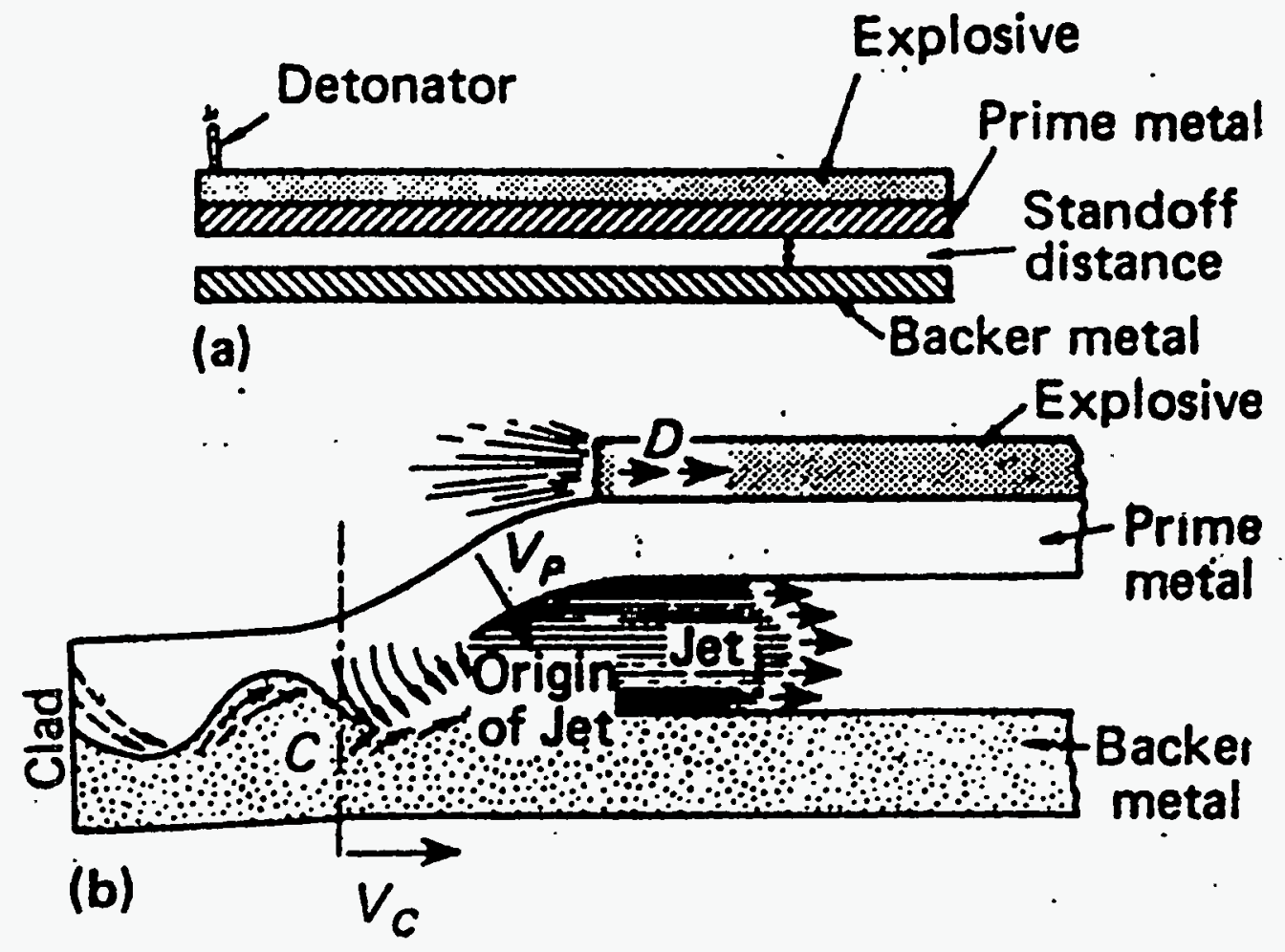

Figure 10. Schematic diagram of parallel arrangement for explosion bonding and subsequent collision between the prime and backer metals that leads to jetting and formation of wavy bond zone (2) 


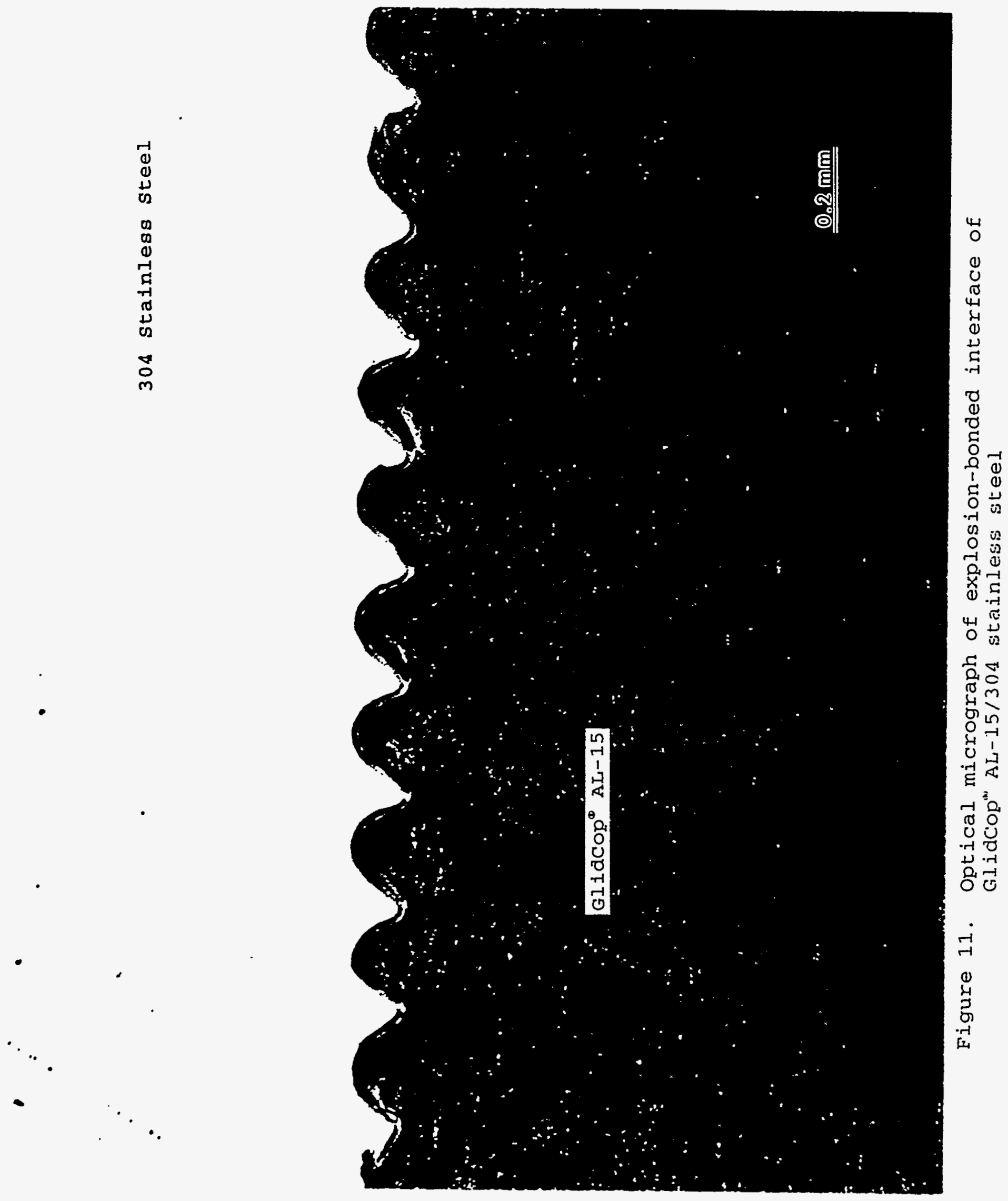




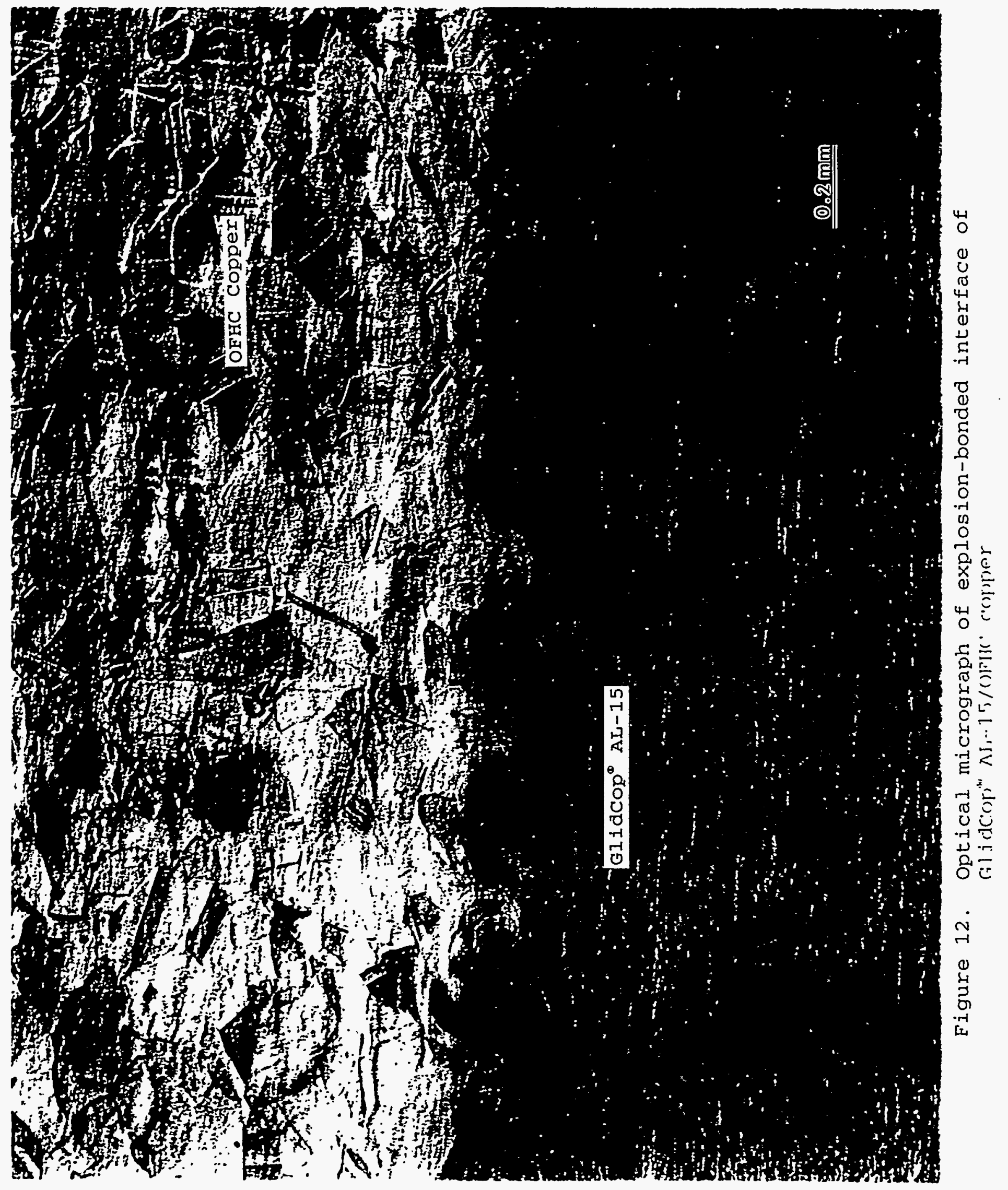




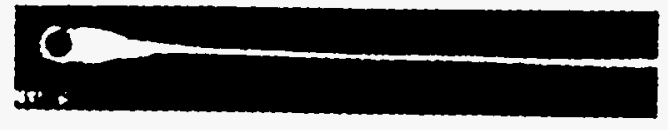

(a)

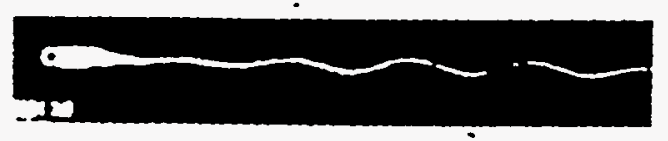

(b)

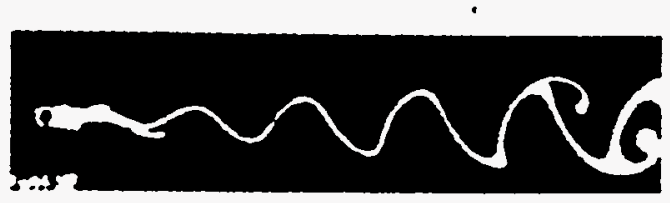

(c)

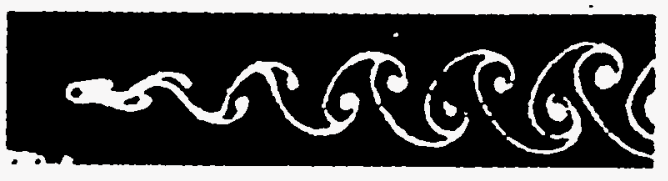

(d)

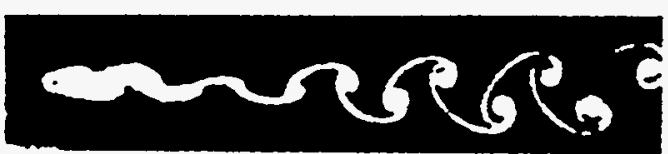

(e)

Figure 13. Wavy bond formation of explosion bonding is analogous to fluid flowing around an obstacle 


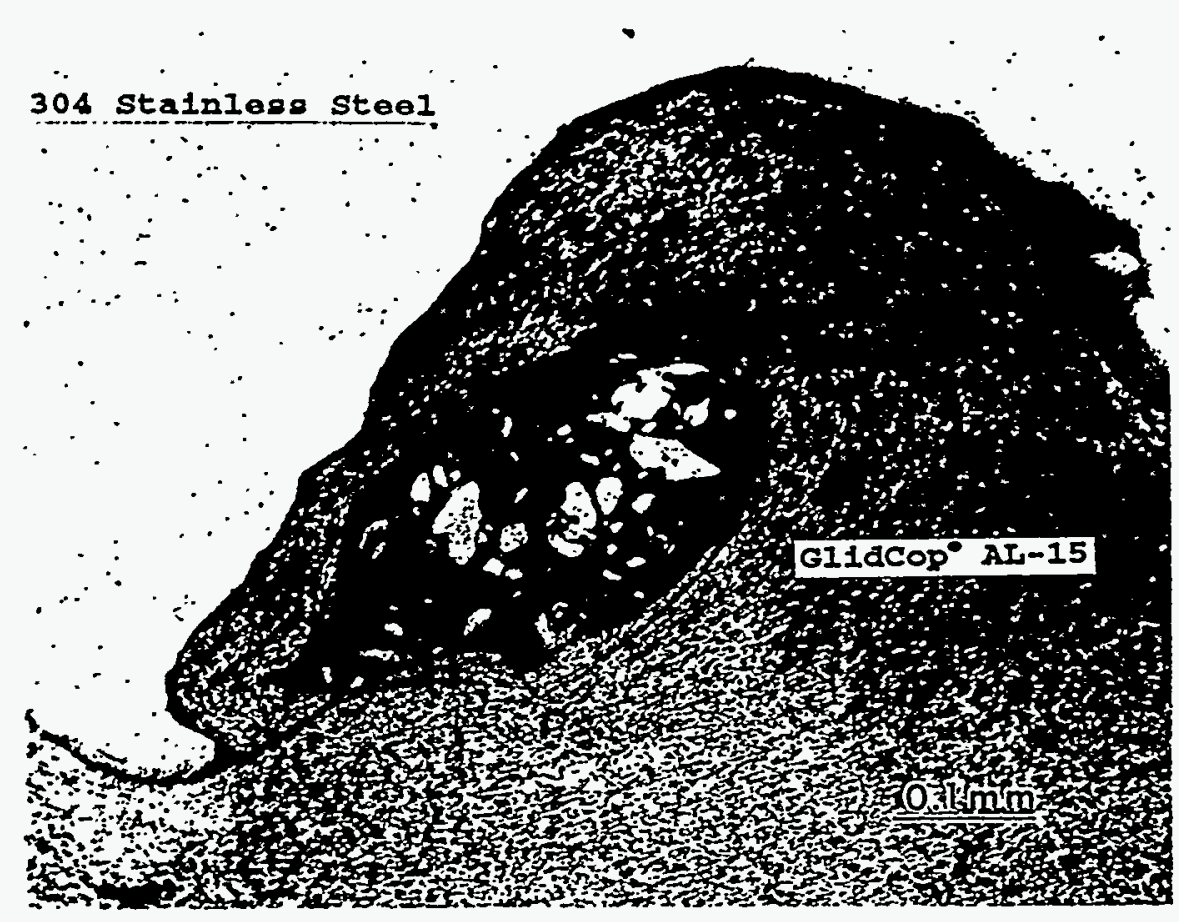

Figure 14. Optical micrograph oミ oxides and other contaminants trapped in turbulent waves 


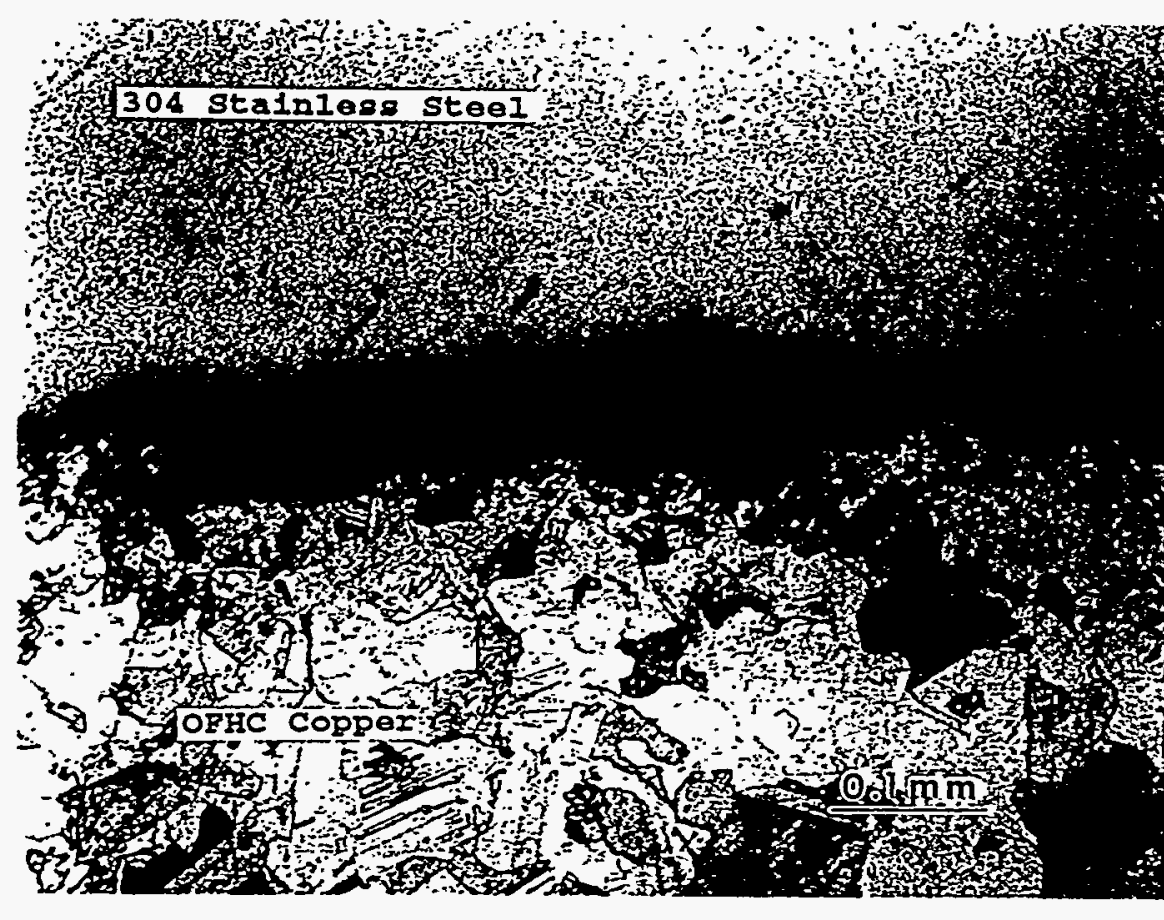

Figure 15. Optical micrograph of brittle intermetallic compounds created in the 304 stainless steel/OFHC copper exwiosion-bonded interface by over-heating during the ars welding process 